\title{
Performance optimization of the fungal biodegradation of $\alpha$-pinene in gas-phase biofilter
}

Yaomin Jin, María C. Veiga, Christian Kennes

Process Biochemistry, Volume 41, Issue 8, August 2006, Pages 1722-1728

DOI: $10.1016 /$ j.procbio.2006.03.020

\begin{abstract}
A Ophiostoma species using $\alpha$-pinene as the sole source of carbon and energy converted it into biomass, carbon dioxide and water. The strain was inoculated in a biofilter fed $\alpha-$ pinene polluted air, and it remained the dominant biocatalyst throughout the study. Near complete removal was observed up to a load of $100 \mathrm{~g} \mathrm{~m}^{-3} \mathrm{~h}^{-1}$, while $89 \%$ removal efficiency was reached at an elimination capacity of $143 \mathrm{~g} \mathrm{~m}^{-3} \mathrm{~h}^{-1}$. The influence of gas flow rate, pollutant concentration and load was evaluated. For a similar load, the highest removal efficiency and corresponding elimination capacity were reached at the lowest flow rate and at an inlet concentration of $2.47 \mathrm{~g} \mathrm{~m}^{-3}$. Oxygen had a significant effect on the removal efficiency since the maximum $\alpha$-pinene degradation rate exceeded $187 \mathrm{~g} \mathrm{~m}^{-3} \mathrm{~h}^{-1}$ at $45 \%$ oxygen in the inlet air suggesting that at high loads oxygen transfer becomes limiting. Biokinetic studies led to a good fit between experimental data and mathematical equations, yielding a calculated maximum $\alpha$-pinene degradation rate of $198.42 \mathrm{~g} \mathrm{~m}^{-3} \mathrm{~h}^{-1}$ with a half-velocity constant, $K_{\mathrm{S}}$, of $0.76 \mathrm{~g} \mathrm{~m}^{-3}$.
\end{abstract}

\section{Keywords}

Biokinetics; $\alpha$-Pinene; Filamentous fungi; Biofiltration; Lava rock 


\section{Introduction}

Emissions of volatile organic compounds (VOCs) have recently become of increasing regulatory concern. Off-gases can be treated by means of various technologies such as absorption, adsorption, scrubbing, and thermal or catalytic oxidation [1]. Over the past decades much effort has been made to develop and improve biological treatment technologies due to their low cost, operational simplicity, and minimum secondary pollution. Biofiltration is currently an accepted and mature technique to treat large volumes of waste gases with low pollutant concentrations [2].

Wood industries represent an important industrial sector in regions of the Northwest of Spain, Scandinavia, South America, and Canada, among others. $\alpha$-Pinene $\left(\mathrm{C}_{10} \mathrm{H}_{16}\right)$ is a hydrophobic and recalcitrant volatile organic compound emitted from the forest products industry (e.g., wood products, pulp and paper industries) with a maximum water solubility of $5-10 \mathrm{mg} \mathrm{l}^{-1}$. It contributes to the formation of photochemical smog and tropospheric ozone [3]. Because of its low solubility in water, the compound is poorly absorbed by the bacterial biofilms. In addition, acidification and drying out of the filter bed often cause biofilter failure. This is why a fungal biofilter was chosen in the present study. For $\alpha$-pinene abatement, filamentous fungi were isolated from biofilters operated in our laboratory. Fungi develop hyphae which provide a large surface area in contact with the gas phase so that a direct efficient mass transfer from the gas phase to the biological aqueous phase is possible. This allows a faster uptake of hydrophobic compounds than in flat aqueous bacterial biofilms [4]. Furthermore, fungi are generally tolerant to low water activities and a low $\mathrm{pH}$, so that these parameters do not need to be strictly monitored in the biofilters [5].

Some researchers have isolated microorganisms that grow with $\alpha$-pinene as sole carbon source. Most of them are bacteria such as Pseudomonas strain PL, Pseudomonas fluorescens NCIMB 11671, Pseudomonas PX1 (NCIMB 10684), Pseudomonas putida PIN11, Nocardia P18.3, Pseudomonas PL and PIN 18 (NCIMB 10687) [6]. Most of the published research data focused on the degradation pathway of $\alpha$-pinene. Recently, Savithiry et al. [7] reported that a thermophilic Bacillus strain, Bacillus pallidus BR425 was isolated from an $\alpha$-pinene enrichment culture. Farooq et al. [8] isolated a plant pathogenic fungus, Botrytis cinerea that could biotransform the $\alpha$-pinene into $3 \beta$ hydroxy-(-)- $\beta$-pinene, 9-hydroxy-(-)- $\alpha$-pinene, $4 \beta$-hydroxy-(-)- $\alpha$-pinene-6-one, and verbenone. Agrawal and Joseph [9] also isolated an Aspergillus niger strain that converts $\alpha$-pinene into verbenone.

Until now there is no published study on the inoculation of fungi as pure biocatalyst in a bioreactor treating waste gases polluted with $\alpha$-pinene (Table 1 ) nor on the complete mineralization of that pollutant by fungal strains. Therefore, the goal of the present work was to obtain fungi capable to metabolize it and verify their efficiency in purifying waste gases in a biofilter. Several experimental runs were carried out in order to investigate the best operational conditions for reaching a high removal efficiency, in terms of pollutant concentration, nutrients addition, gas flow rate, load, and oxygen concentration. Besides, relevant biokinetic parameters were calculated. 
Table 1.

Performance of biofilters treating $\alpha$-pinene

\begin{tabular}{|c|c|c|c|c|}
\hline Media & $\begin{array}{l}\text { Inlet } \\
(\mathrm{ppm})\end{array}$ & \begin{tabular}{|l} 
EBRT \\
$(\mathbf{s})$
\end{tabular} & $\begin{array}{l}\text { Performance } \\
\left(\mathrm{g} \mathrm{m}^{-3} \mathbf{h}^{-1}\right)\end{array}$ & Ref. \\
\hline $\begin{array}{l}\text { Perlite; expanded clay granules; } \\
\text { polyurethane foam cubes; } \\
\text { compost }\end{array}$ & | 71 & $18-36$ & $24 ; 33 ; 38 ; 24$ & |[10] \\
\hline Proprietary wood waste & $1-100$ & 120 & 6 & {$[11]$} \\
\hline BIOSCRUB RBC & $25-35$ & $13-24$ & $2.7-4.2$ & {$[12]$} \\
\hline Aspen wood chips & |6-451 & $\begin{array}{l}1248- \\
1812 \\
\end{array}$ & $\mid 3.9$ & $\mid[13]$ \\
\hline Celite R-635 & $\mid 15$ & $\begin{array}{l}660 \\
1080 \\
\end{array}$ & $\mid 3.5$ & |[14] \\
\hline $\begin{array}{l}\text { Wood, compost, and perlite } \\
\text { mixture }\end{array}$ & |30-35 & 50 & $\mid 10-12$ & $\mid[15]$ \\
\hline Wood chips & $38-109$ & $20 ; 60$ & $14.6-44.6$ & {$[16]$} \\
\hline Lava rock & |2-739 & $\begin{array}{l}26 ; 38 ; \\
72\end{array}$ & 143 & $\begin{array}{l}\text { Present } \\
\text { study }\end{array}$ \\
\hline
\end{tabular}

\section{Material and methods}

\subsection{Media composition}

Batch experiments were undertaken with an aqueous culture medium containing (per liter) [17]: $4.5 \mathrm{~g} \mathrm{KH}_{2} \mathrm{PO}_{4}, 0.5 \mathrm{~g} \mathrm{~K}_{2} \mathrm{HPO}_{4}, 2.0 \mathrm{~g} \mathrm{NH}$ culture medium was autoclaved at $120^{\circ} \mathrm{C}$ for $20 \mathrm{~min}$ before adding filter-sterilized solutions of vitamins and trace minerals. The composition of the vitamin solution was (per liter): $0.2 \mathrm{~g}$ thiamine $\mathrm{HCl}, 0.1 \mathrm{~g}$ riboflavin, $1.0 \mathrm{~g}$ nicotinic acid, $2.0 \mathrm{~g} \mathrm{Ca}-$ pantothenate, $0.1 \mathrm{~g}$ biotin, $0.1 \mathrm{~g}$ thioctic acid, $0.1 \mathrm{~g}$ folic acid and $0.25 \mathrm{~g}$ pyridoxine $\mathrm{HCl}$. The composition of the trace minerals solution was (per liter): $120 \mathrm{mg} \mathrm{FeCl}_{3}$, $50 \mathrm{mg} \mathrm{H}_{3} \mathrm{BO}_{3}, 10 \mathrm{mg} \quad \mathrm{CuSO}_{4} \cdot 5 \mathrm{H}_{2} \mathrm{O}, 10 \mathrm{mg} \quad \mathrm{KI}, 45 \mathrm{mg} \quad \mathrm{MnSO}_{4} \cdot \mathrm{H}_{2} \mathrm{O}, 20 \mathrm{mg}$ $\mathrm{Na}_{2} \mathrm{MoO}_{4} \cdot 2 \mathrm{H}_{2} \mathrm{O}, 75 \mathrm{mg} \mathrm{ZnSO} \cdot 7 \mathrm{H}_{2} \mathrm{O}, 50 \mathrm{mg} \mathrm{CoCl} \cdot 6 \mathrm{H}_{2} \mathrm{O}, 20 \mathrm{mg} \mathrm{KAl}\left(\mathrm{SO}_{4}\right)_{2} \cdot 12 \mathrm{H}_{2} \mathrm{O}$, $13.25 \mathrm{mg} \mathrm{CaCl} \cdot 2 \mathrm{H}_{2} \mathrm{O}$ and $10,000 \mathrm{mg} \mathrm{NaCl}$. The original $\mathrm{pH}$ of that medium was 5.9.

Stock cultures of the fungi were maintained on petri dishes or on slants using either potato dextrose agar (PDA) or the same mineral medium as described above

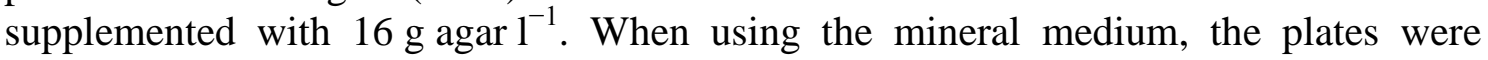
incubated in a tank or a desiccator at $30{ }^{\circ} \mathrm{C}$, in the presence of $\alpha$-pinene vapors as sole carbon source. Stock cultures on PDA were stored in a refrigerator at $4{ }^{\circ} \mathrm{C}$.

\subsection{Enrichment and isolation of $\alpha$-pinene degrader}

Biomass from a biofilter treating toluene was mixed with sludge and inoculated in a biofilter fed $\alpha$-pinene-polluted air. The $\alpha$-pinene degrading fungus used in this study was obtained from the leachate of the biofilter treating $\alpha$-pinene. Ten milliliters of the 
liquid were suspended in $90 \mathrm{ml}$ mineral medium as described elsewhere [17]. $\alpha$-Pinene was added as the only source of carbon and energy. Erlenmeyer flasks with a 5:1 headspace/liquid ratio were closed with Teflon wrapped rubber stoppers and were incubated in a rotary shaker $(150 \mathrm{rpm})$ at $35^{\circ} \mathrm{C}$. The flasks were aerated daily, and $\alpha-$ pinene was added as needed. After several serial transfers, stable microbial consortia developed. Individual members of the consortia were isolated by streaking on mineral agar medium and incubation under solvent vapor. The isolated strain was sent to the Central Bureau voor Schimmelcultures (The Netherlands) for identification.

\section{3. $\alpha$-Pinene biodegradation in batch assays}

Batch assays were performed at least in duplicate, with the corresponding controls. Both uninoculated media (called "blanks") and inoculated autoclaved vials (called "controls") were used. The mineral medium described above $(200 \mathrm{ml})$ was introduced into $500 \mathrm{ml}$ bottles closed with Viton septa and screw caps. The pollutant was added, to reach a gasphase concentration of about $28 \mathrm{mg} \mathrm{l}^{-1}$ air. Although data are reported as gas-phase concentrations, the substrate is a volatile compound and is distributed between the gas and liquid phases. As described below, biodegradation was followed by sampling the gas phase. The concentration in the liquid phase can easily be calculated based on Henry's partition coefficient. A stock culture of the fungus was used as inoculum. That stock culture was grown in the mineral medium with $\alpha$-pinene until reaching an optical density of 0.2 at $660 \mathrm{~nm}$. After homogenization, $10 \mathrm{ml}$ of that stock culture was inoculated into the bottles for the biodegradation assays, allowing all experiments to start with identical biomass concentrations. The bottles were maintained in a thermostatic shaker at $30{ }^{\circ} \mathrm{C}$ with constant shaking at $200 \mathrm{rpm}$.

\subsection{Biofilter operation}

The schematic of the biofilter used in this study is shown in Fig. 1. It is a cylindrical packed-bed reactor made of glass, $75 \mathrm{~mm}$ in diameter and $700 \mathrm{~mm}$ in height. The active height of packing column, filled with lava rock, was $250 \mathrm{~mm}$. The cylindrical glass column contained four equidistant sampling ports. All fittings, connections and tubings were made of Teflon. A large stream of compressed air was humidified up to $97 \%$ relative humidity by passing it through a packing tower humidified with water. A small stream of air was bubbled through a vial containing pure $\alpha$-pinene and was mixed with the larger humidified gas stream. Gas-phase $\alpha$-pinene concentrations ranging from 0 to $739 \mathrm{ppm}$ were obtained by changing the relative flow rates of the gas streams. The resulting synthetic waste gas was introduced through the top of the column in a cocurrent flow. An aqueous mineral medium was added over the packed bed once a week in order to add fresh nutrients and remove any accumulated metabolites. The $\mathrm{pH}$ of the leachate was measured. For inoculation, the fungus was first grown in liquid medium with $\alpha$-pinene as sole carbon and energy source. Then, the biofilter was filled with that solution and the liquid phase was drained off after $1 \mathrm{~h}$. Afterwards, $\alpha$-pinene was fed to the biofilter. 


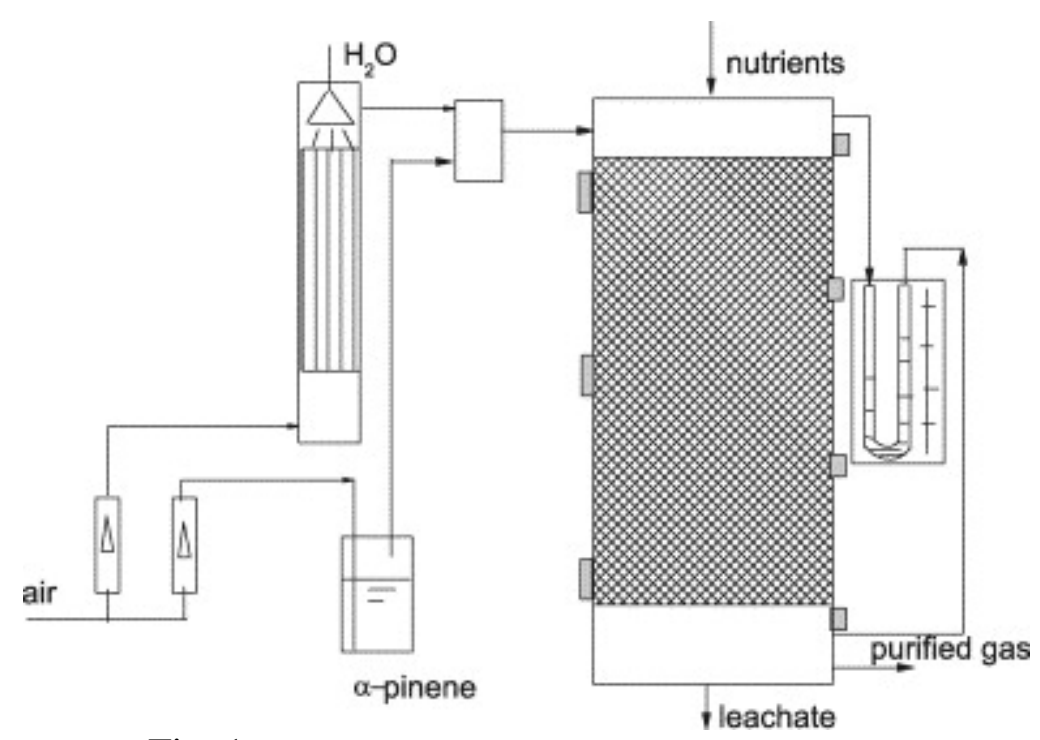

Fig. 1.

Schematic of the laboratory scale biofilter.

During the experimental study on the effect of $\mathrm{O}_{2}$, pure oxygen from a gas cylinder flew first through a pressure gauge (RBDE-30/PS-3.5, Carburos Metalicos S.A., La Coruña, Spain) and then through a flowmeter (Model VCD 1000 flow controller, Porter Instrument Co. Inc., Hatfield, PA, USA) in order to reach $45 \% \mathrm{O}_{2}$ concentration in the inlet gas.

\subsection{Analytical methods}

Gas-phase concentrations of $\alpha$-pinene in the biofilters were measured using a HewlettPackard 5890 series II gas chromatograph (GC). The GC was equipped with a flame ionization detector (FID) maintained at $250{ }^{\circ} \mathrm{C}$. The flow rates were $30 \mathrm{ml} \mathrm{min}^{-1}$ for $\mathrm{H}_{2}$ and $300 \mathrm{ml} \mathrm{min}^{-1}$ for air. The inlet and outlet streams of the biofilter were sampled, as well as air aliquots taken at different reactor heights. The GC was equipped with a $50 \mathrm{~m}$ TRACER column (TR-WAX, internal diameter $0.32 \mathrm{~mm}$, film thickness $1.2 \mu \mathrm{m}$ ) and helium was used as the carrier gas at a flow rate of $2.0 \mathrm{ml} \mathrm{min}^{-1}$. The $\alpha$-pinene concentration was determined at the oven temperature of $120^{\circ} \mathrm{C}$. Similarly, $\mathrm{CO}_{2}$ concentrations were measured on another Hewlett-Packard 5890 series II GC equipped with a thermal conductivity detector (TCD). The $\mathrm{CO}_{2}$ concentrations were determined at an injection temperature of $90^{\circ} \mathrm{C}$, an oven temperature of $25^{\circ} \mathrm{C}$ and using a TCD at $100{ }^{\circ} \mathrm{C}$. The head loss across the biofilter bed was measured by a U-tube manometer filled with water (Fig. 1).

\section{Results and discussion}

\subsection{Microorganism identification}

The recently isolated organism used for the present studies was identified as Ophiostoma species. This organism formed a filamentous network when grown in packed-bed reactors such as the gas-phase biofilter used in this work ( Fig. 2). This is an interesting characteristic, since it has been suggested that the growth of filamentous 
organisms enhances the mass transfer of hydrophobic pollutants from the gas to the biocatalyst, thereby improving the performance of biofilters.

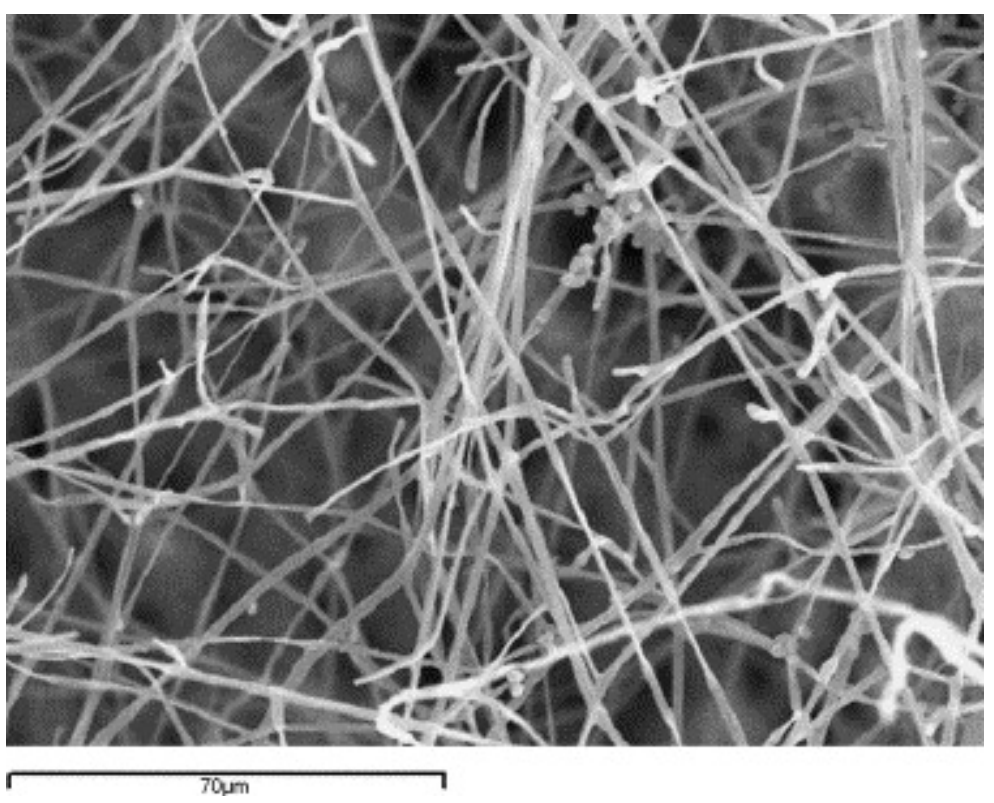

Fig. 2.

SEM picture of a filter-bed sample from a gas-phase packed-bed bioreactor colonized by a culture of Ophiostoma species.

\subsection{Batch assays and biomass yield}

The Ophiostoma species was transferred to the aqueous nutritive solution at $\mathrm{pH} 5.9$ with $\alpha$-pinene as the sole carbon source, demonstrating its ability to use that compound as single carbon and energy source ( Fig. 3). Carbon dioxide was identified as end-product, the rest of the substrate being converted into biomass ( Fig. 4). To the best of our knowledge, this is the first report on the complete biodegradation of $\alpha$-pinene by a pure fungal culture.

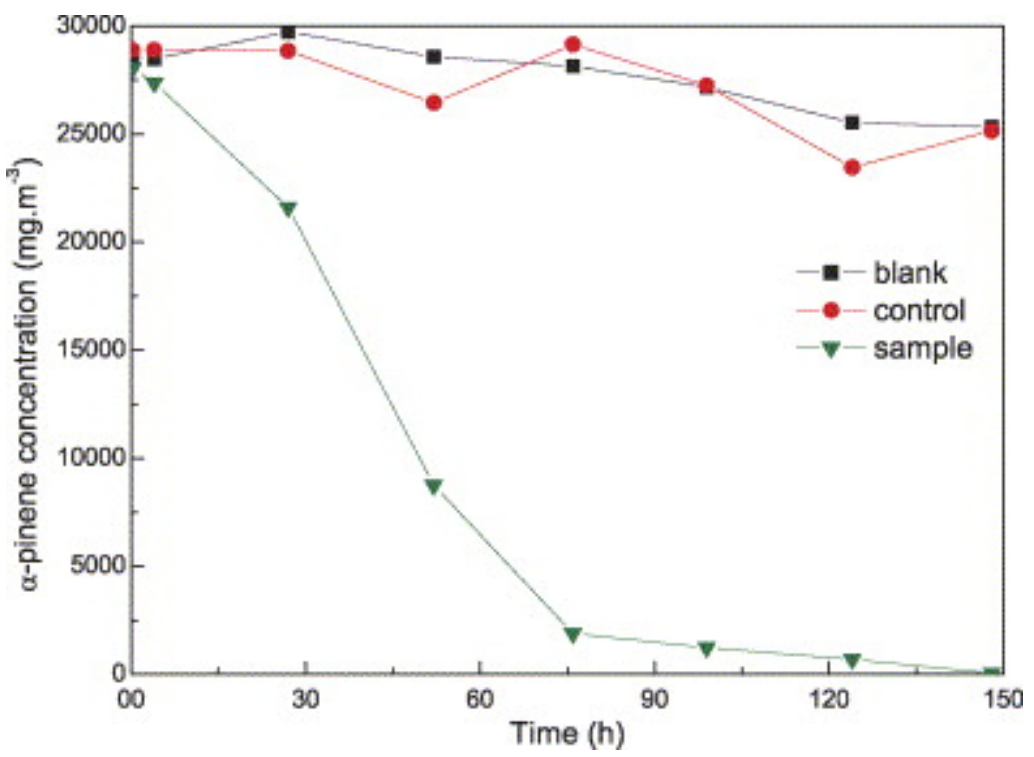


Fig. 3.

Biodegradation of $\alpha$-pinene by Ophiostoma species.

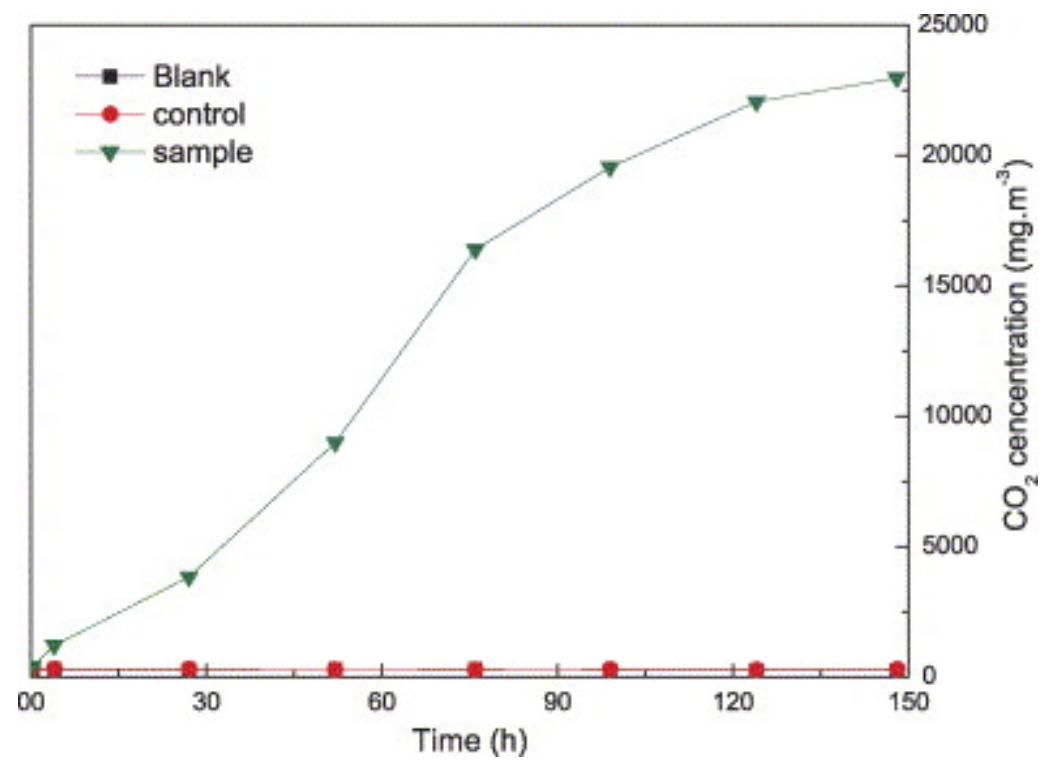

Fig. 4.

$\mathrm{CO}_{2}$ production during the biodegradation of $\alpha$-pinene by Ophiostoma species.

The yield coefficient of biomass on $\alpha$-pinene has been determined from the shake flask experiments as $1.25 \mathrm{~kg}$ dry biomass $/ \mathrm{kg} \alpha$-pinene consumed. A typical cellular composition can be represented by the formula $\mathrm{C}_{5} \mathrm{H}_{7} \mathrm{NO}_{2}[1]$. Taking into account the fact that $\mathrm{NH}_{4} \mathrm{Cl}$ was the nitrogen source and considering the yield coefficient, one can deduce the following stoichiometric equation:

$\mathrm{C}_{10} \mathrm{H}_{16}+6.5 \mathrm{O}_{2}+1.5 \mathrm{NH}_{4} \mathrm{Cl} \rightarrow 1.5 \mathrm{C}_{5} \mathrm{H}_{7} \mathrm{NO}_{2}+5 \mathrm{H}_{2} \mathrm{O}+2.5 \mathrm{CO}_{2}+1.5 \mathrm{HCl}$

\subsection{Influence of the inlet $\alpha$-pinene concentration and gas flow rate}

Fig. 5 shows the removal efficiencies as a function of the $\alpha$-pinene concentration at different volumetric flow rates of the gas stream during biofilter operation. A gradual decrease in efficiency was observed as the pollutant concentration increased, showing a higher elimination efficiency under conditions of low flow rate. The removal efficiency of the biofilter remained higher than $90-95 \%$ up to an inlet concentration of about $400 \mathrm{ppm}$, at an air flow rate of $0.055 \mathrm{~m}^{3} \mathrm{~h}^{-1}$. At such flow rate, a maximum elimination capacity of $143 \mathrm{~g} \mathrm{~m}^{-3} \mathrm{~h}^{-1}$ was reached when feeding $444 \mathrm{ppm} \alpha$-pinene, corresponding to $2.47 \mathrm{~g} \mathrm{~m}^{-3}$ (Fig. 6). When using higher flow rates, the elimination capacities reached 65 and $57 \mathrm{~g} \mathrm{~m}^{-3} \mathrm{~h}^{-1}$, at 0.105 and $0.155 \mathrm{~m}^{3} \mathrm{~h}^{-1}$, respectively. For similar loads, the optimum inlet concentration corresponding to the highest elimination capacity ranged from 120 to $400 \mathrm{ppm}$ depending on the gas flow rate. Within this range, the elimination capacity increased with increasing inlet concentrations for the low gas flow rate $\left(0.055 \mathrm{~m}^{3} \mathrm{~h}^{-1}\right)$, but it decreased at the highest gas flow rate $\left(0.155 \mathrm{~m}^{3} \mathrm{~h}^{-1}\right)$. Thus, as shown in Fig. 6, the optimum inlet concentration and the corresponding elimination capacity are decreasing functions of the gas flow rate. These data suggest that fungal 
biofilters would be highly efficient at relatively high inlet concentrations combined with moderate flow rates. High flow rates, i.e. short residence times, result in reduced efficiencies.

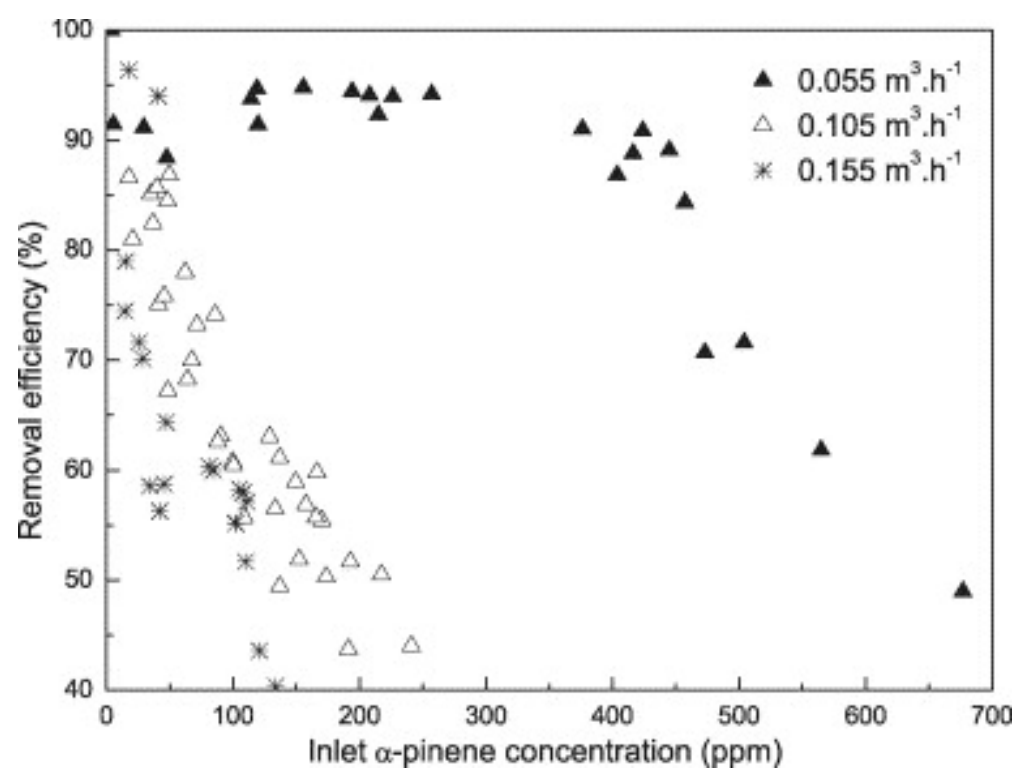

Fig. 5.

Removal efficiency of the biofilter as a function of the inlet concentration of $\alpha$ pinene, at different flow rates of the gas stream.

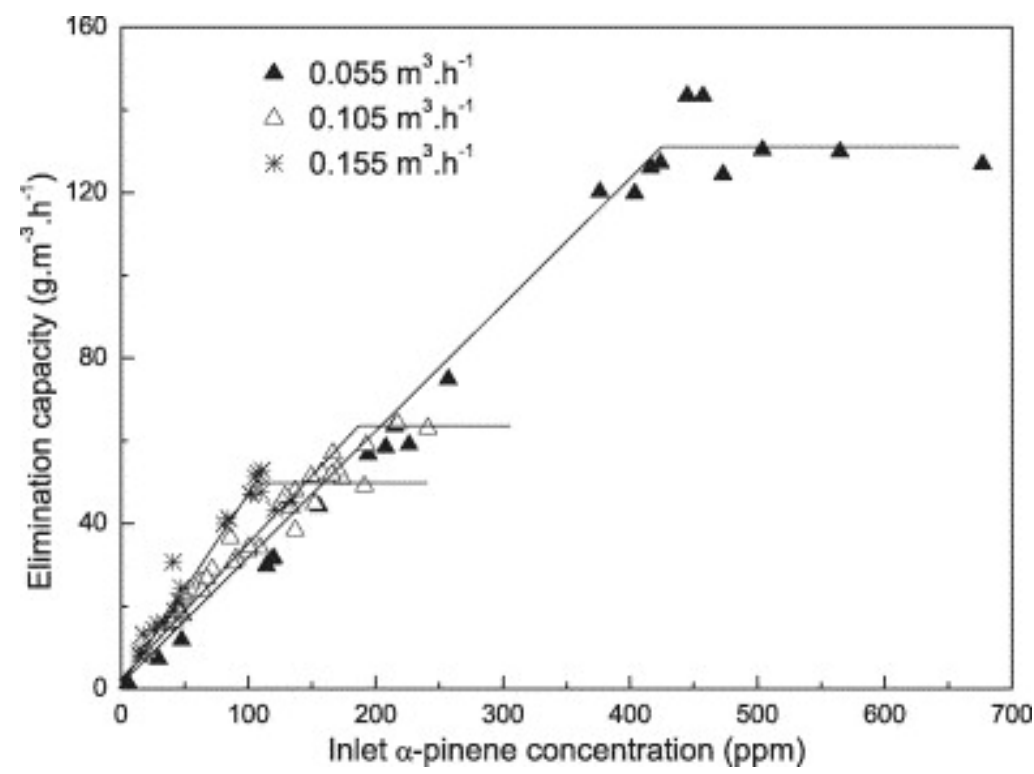

Fig. 6.

$\alpha$-Pinene elimination capacity vs. the inlet load for various gas flow rates obtained in the biofilter.

\subsection{Load effect on the elimination capacity}

The effect of the $\alpha$-pinene load on the biofilter's elimination capacity was evaluated at a gas flow rate of $0.055 \mathrm{~m}^{3} \mathrm{~h}^{-1}$ (Fig. 7). The relationship was linear up to a critical value, after which the elimination capacity approached a maximum value asymptotically. The 
removal efficiency was close to $100 \%$ below the critical inlet load of $100 \mathrm{~g} \mathrm{~m}^{-3} \mathrm{~h}^{-1}$ and a maximum elimination capacity of $143 \mathrm{~g} \mathrm{~m}^{-3} \mathrm{~h}^{-1}$ was obtained at an inlet load of $161 \mathrm{~g} \mathrm{~m}^{-3} \mathrm{~h}^{-1}$ or higher, still yielding a high removal efficiency of $89 \%$. The maximum elimination capacity obtained with this Ophiostoma species was 3-50 times higher than the values obtained using bacteria-dominant systems ( Table 1). Although studies on fungal biofilters started only a few years ago, several researchers have reported and shown experimentally that fungal biofilters may offer contaminant removal rates equal or greater than those observed in bacterial systems [4] and [5].

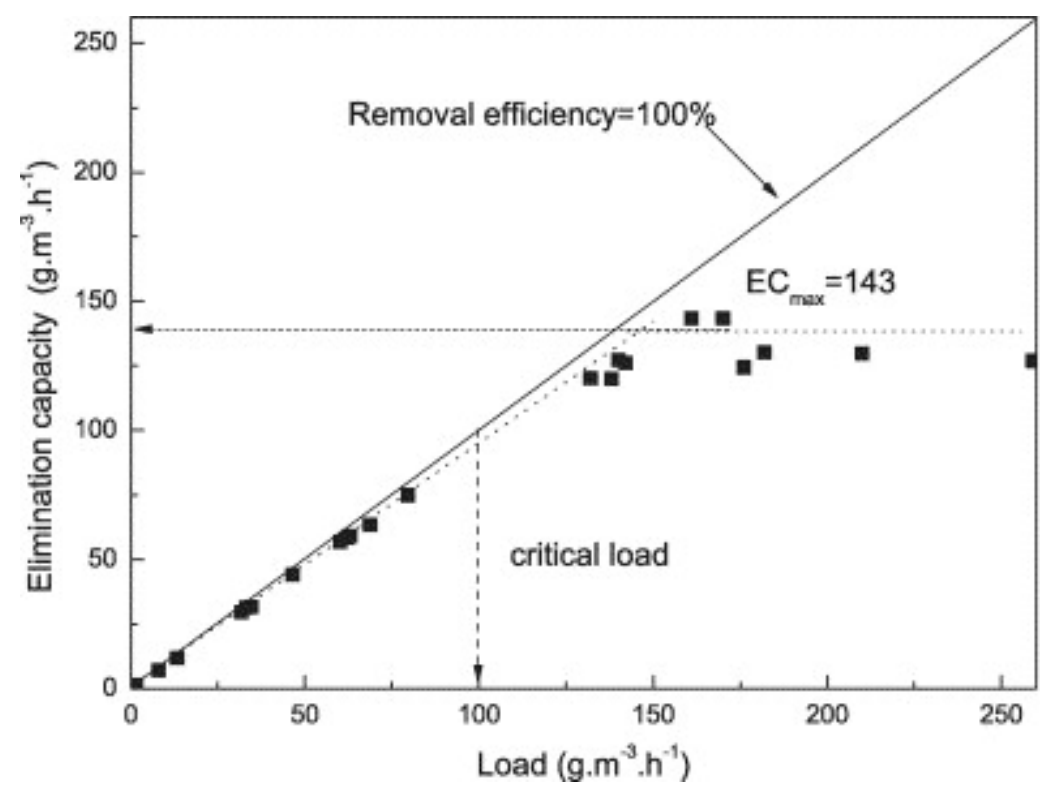

Fig. 7.

Load effect on $\alpha$-pinene elimination capacity.

\section{5. $\mathrm{pH}$ evolution and pressure drop in the biofilter}

The assimilation of ammonium nitrogen $\left(\mathrm{NH}_{4}{ }^{+}-\mathrm{N}\right)$ results in a decrease of the $\mathrm{pH}$ of the medium. If the medium can neutralize the protons released from the assimilation of the nitrogen source, the $\mathrm{pH}$ will be relatively constant. Otherwise, acidification of the filter bed will occur.

The $\mathrm{pH}$ of the aqueous solution drained from the biofilter following the regular nutrient addition procedure was around 5.0. However, inside the biofilter, the fungi still grew, even at this low $\mathrm{pH}$ value, during the periods between the weekly nutrient additions. For the fungal biofilter used in this research, the $\mathrm{pH}$ drop did never exhibit any apparent adverse impact on the reactor's performance.

Compared to bacterial systems, the filamentous fungi may cause some higher head losses due to the fact that fungal biomass fills the pore spaces of the packing media. This may eventually lead to channeling and clogging problems in the biofilter, which ends up in a reduced efficiency. In the fungal biofilter treating $\alpha$-pinene, no significant pressure drop was detected, even after 6 months operation. This demonstrated that lava rock is a very suitable packing material for use in this fungal biofilter. 


\subsection{Carbon dioxide balance}

In the biofiltration process, $\alpha$-pinene is converted under aerobic conditions to carbon dioxide, water, and biomass. Hence, monitoring the carbon dioxide concentration in the gas phase provides valuable information on the operation of the biofilter and on the extent of mineralization of the pollutant. The ratio of daily measurements of the carbon dioxide production and removal of $\alpha$-pinene are summarized in Fig. 8 . The measurements in Fig. 8 show that this ratio was rather constant. Experimental data reveal that the variation of $\mathrm{RCO}_{2} \mathrm{RCO} 2$ versus $\mathrm{RC} 10 \mathrm{H} 16 \mathrm{RC} 10 \mathrm{H} 16$ is sensibly linear. The equation of the line shown in Fig. 8 is $y=11 x$. Thus, the slope of this line is 11 indicating that the average ratio of the measured $\mathrm{RCO}_{2} \mathrm{RCO} 2$ to RC10H16RC10H16 was equal to 11 with a correlation coefficient of 0.99 . The theoretical number of moles of carbon dioxide that should be produced per mole of $\alpha$-pinene eliminated should not exceed 10, even when neglecting biomass growth, since 1 mole of $\alpha$-pinene with 10 carbon atoms $\left(\mathrm{C}_{10} \mathrm{H}_{16}\right)$ would yield 10 moles of carbon dioxide. If biomass growth is accounted for, this value should even be lower, as indicated earlier. However, the experimental value was somewhat higher than 10. The discrepancy between these two ratios may result from the following events: (1) even when no $\alpha$-pinene was added to the reactor, there was still some $\mathrm{CO}_{2}$ generated by endogenous respiration, (2) there is some carbonate of the lava rock packing dissolved by the acid released from $\mathrm{NH}_{4}{ }^{+}$ assimilation, this reaction may cause some additional $\mathrm{CO}_{2}$ emission too.

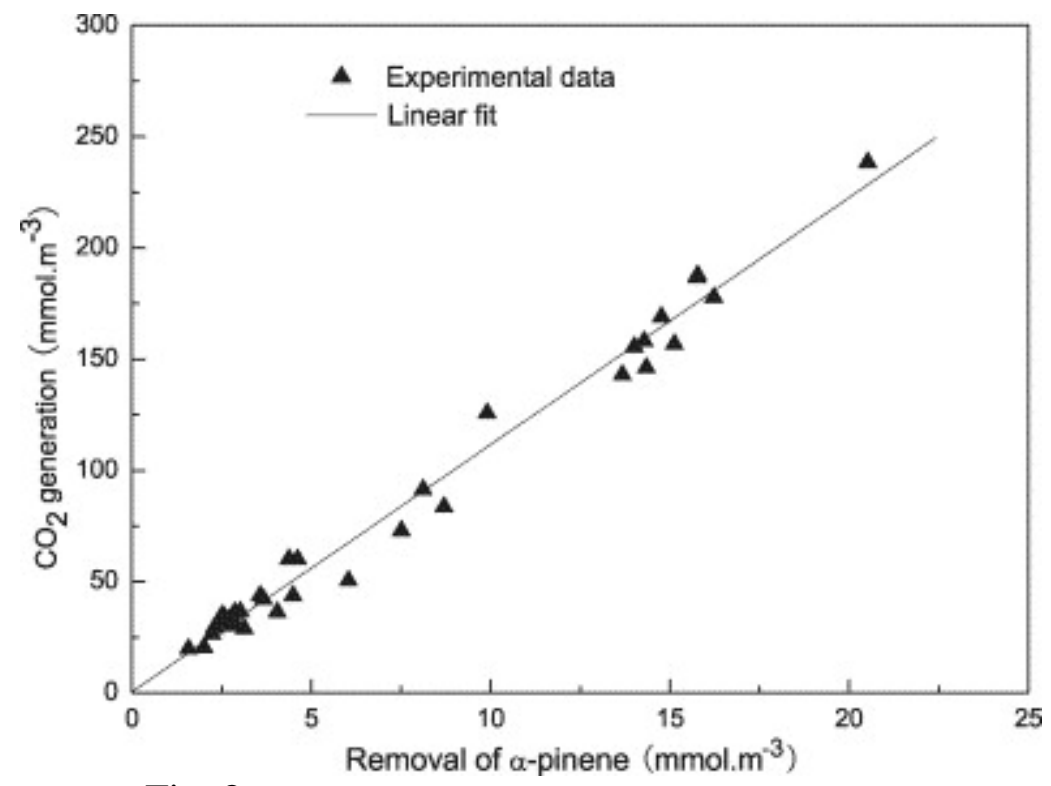

Fig. 8.

Carbon dioxide produced vs. the elimination capacity of $\alpha$-pinene.

Other authors also observed that the $\mathrm{CO}_{2}$ recovery in gas-phase biofilters may sometimes exceed $100 \%$ as a result of high rates of endogenous respiration [18]. It was shown that after long-term operation this may be the dominant $\mathrm{CO}_{2}$ generation process. This would also explain the negligible pressure drop observed in our system and described above, due to limited biomass accumulation and significant endogenous respiration. 
In any case, the high $\mathrm{CO}_{2}$ recovery confirms the data of batch assays and indicates that the removed $\alpha$-pinene is eliminated by biodegradation rather than by any other physical or chemical process such as adsorption. It can be concluded that $\alpha$-pinene was basically completely transformed into $\mathrm{CO}_{2}$.

\subsection{Influence of $\mathrm{O}_{2}$ on performance}

In this experiment the influence of the oxygen concentration was investigated by comparison of $\alpha$-pinene degradation and $\mathrm{CO}_{2}$ production rates at $21 \%$ (air) and $45 \%$ oxygen (air enriched with pure oxygen) in the inlet gas.

According to the data shown in Fig. 9, the degradation rate of $\alpha$-pinene shows a linear relationship with the inlet concentration. However, the removal efficiency of $\alpha$-pinene decreased when increasing the inlet concentration. The maximum $\alpha$-pinene degradation rate increased from 143 to $187 \mathrm{~g} \mathrm{~m}^{-3} \mathrm{~h}^{-1}$ with $45 \%$ oxygen in the gas while no effect on the recovery of removed $\alpha$-pinene as $\mathrm{CO}_{2}$ was observed. This maximum elimination capacity was reached at an inlet pollutant concentration of $739 \mathrm{ppm}$, which is as high as $4.12 \mathrm{~g} \mathrm{~m}^{-3}$. Apparently, the maximum degradation rate at high $\alpha$-pinene concentrations is limited by the availability of oxygen. Contrary to what happened with normal air (i.e., $21 \% \mathrm{O}_{2}$ ) where the elimination capacity leveled off when reaching $125-130 \mathrm{~g} \mathrm{~m}^{-3} \mathrm{~h}^{-1}$ (Fig. 6), such a plateau was not found in presence of $45 \% \mathrm{O}_{2}$ (Fig. 9) suggesting that elimination capacities exceeding $190-200 \mathrm{~g} \mathrm{~m}^{-3} \mathrm{~h}^{-1}$ could reasonably haven been reached if higher loads had been applied.

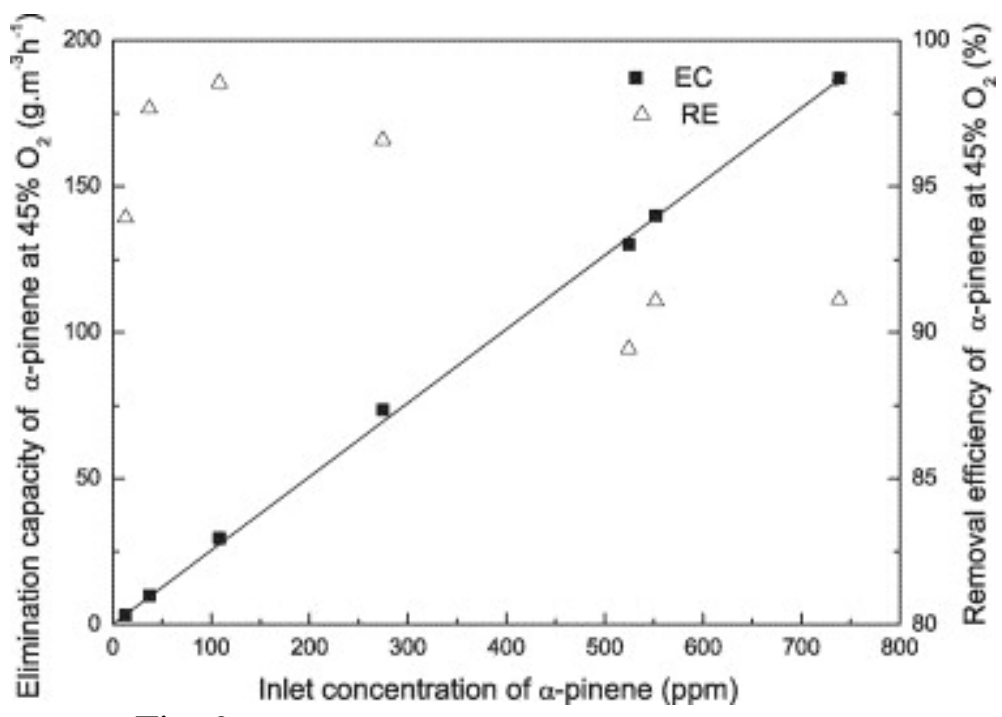

Fig. 9.

Effect of $\mathrm{O}_{2}$ concentration on $\alpha$-pinene removal.

\subsection{Biokinetic parameters calculation from bioreactor data}

Different methods can be used to size biofilters. If a modeling approach is chosen, the knowledge of specific biokinetic parameters is necessary. In the present case, biokinetic parameters were calculated in biofiltration studies undertaken at the optimal air flow rate of $0.055 \mathrm{~m}^{3} \mathrm{~h}^{-1}$. The kinetics for cellular systems can be described by the Monod Equation [1] when no inhibitory effects are observed: 
$\mu=\frac{\mu_{\mathrm{m}} S}{K_{\mathrm{S}}+S}$

The constant $K_{\mathrm{S}}$ is known as the saturation constant or half-velocity constant and is equal to the concentration of the rate-limiting substrate when the specific growth rate is equal to one-half of its maximum value, that is, $K_{\mathrm{S}}=S$ when $\mu=(1 / 2) \mu_{\mathrm{m}}$. In general, $\mu=\mu_{\mathrm{m}}$ for $S \gg K_{\mathrm{S}}$ and $\mu=\left(\mu_{\mathrm{m}} / K_{\mathrm{S}}\right) S$ for $S \ll K_{\mathrm{S}}$.

There is a relationship between the substrate consumption rate and the specific microbial growth rate, that can be described as follows:

$r_{\mathrm{S}}=-\frac{\mathrm{d} S}{\mathrm{~d} t}=\frac{B}{Y_{\mathrm{X} / \mathrm{S}}} \mu=\frac{B \mu_{\mathrm{m}}}{Y_{\mathrm{X} / \mathrm{S}}} \frac{S}{K_{\mathrm{S}}+S}=r_{\mathrm{S}, \max } \frac{S}{K_{\mathrm{S}}+S}$

$r_{\mathrm{S} \text {,max }}$, the maximum substrate degradation rate, corresponds to $B \mu_{\mathrm{m}} / Y_{\mathrm{X} / \mathrm{s}}$.

Considering the mass balance over a small segment of biofilter volume as shown in Fig. 10, one can derive the following equation:

$-\int_{C_{\mathrm{i}}}^{C_{0}} \frac{K_{\mathrm{S}}+S}{S} \mathrm{~d} S=r_{\mathrm{S}, \max } \frac{A}{Q} \int_{0}^{H} \mathrm{~d} z$

After integration over the full height of the biofilter, we obtain:

$$
\left(C_{\mathrm{i}}-C_{\mathrm{o}}\right)+K_{\mathrm{S}} \ln \left(\frac{C_{\mathrm{i}}}{C_{\mathrm{o}}}\right)=r_{\mathrm{S}, \max } \frac{V}{Q}(\mathrm{Ci}-\mathrm{Co})+\mathrm{KS} \operatorname{lnCiCo}=\mathrm{rS}, \max V \mathrm{Q}
$$

The left side of Eq. (4) can be simplified as:

left side $=\left(C_{\mathrm{i}}-C_{\mathrm{o}}\right)\left[1+\frac{K_{\mathrm{S}}}{\left(C_{\mathrm{i}}-C_{\mathrm{o}}\right) / \ln \left(C_{\mathrm{i}} / C_{\mathrm{o}}\right)}\right]$

After substituting $V / Q$ by $C_{\mathrm{i}}-C_{\mathrm{o}} / r_{\mathrm{s}}$, the right side of Eq. (4) becomes:

right side $=r_{\mathrm{S}, \max } \frac{C_{\mathrm{i}}-C_{\mathrm{o}}}{r_{\mathrm{S}}}=\left(C_{\mathrm{i}}-C_{\mathrm{o}}\right)\left(1+\frac{K_{\mathrm{S}}}{\bar{C}}\right)$

where

$\bar{C}=\frac{C_{\mathrm{i}}-C_{0}}{\ln \left(C_{\mathrm{i}} / C_{0}\right)}$

Comparing Eqs. (5) and (6), it appears that there is a relationship between the substrate consumption rate and the mean log of the inlet and outlet concentrations. $r$ s can be expressed as a function of the log mean of the concentrations $\mathrm{C}^{-}$, i.e., $r_{\mathrm{S}}=f(\bar{C})$. 


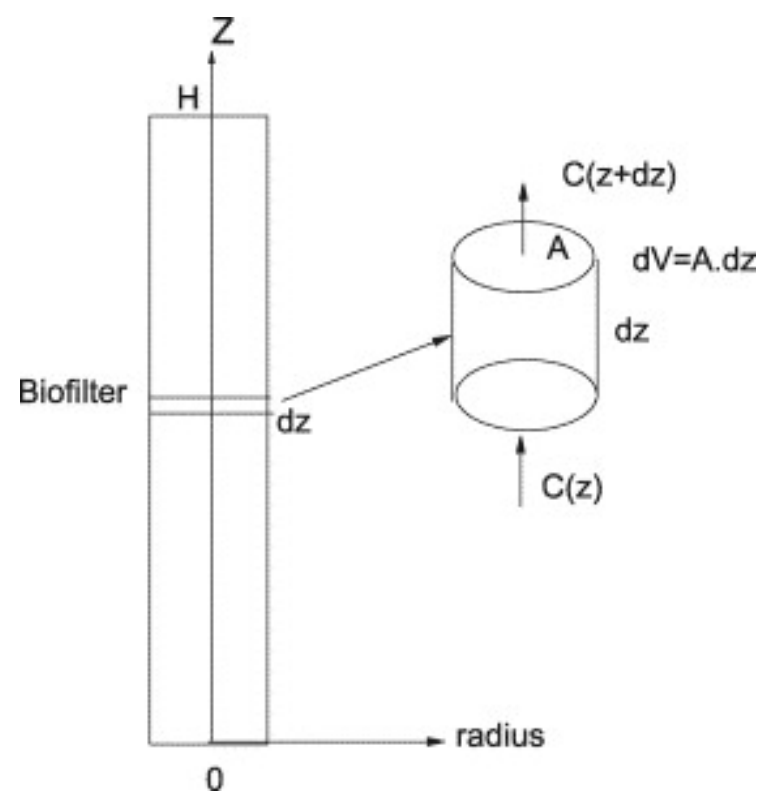

Fig. 10.

Mass balance in biofilter.

Based on the relationship between $r$ s and $\bar{C} C^{-}$, the data can be plotted in order to determine $r_{\mathrm{S} \text {,max }}$ and $K_{\mathrm{S}}$ by non-linear regression of the experimental data at the gas flow rate of $0.055 \mathrm{~m}^{3} \mathrm{~h}^{-1}$ ( Fig. 11). This shows that the data can be fitted satisfactorily by linear regression in the low inlet concentration range, meaning that the bioreaction follows first-order kinetics. However, the degradation rate approaches a constant value at higher concentrations, indicating a shift from first to zero-order kinetics. Under such circumstances, the kinetic parameters for the biofiltration of $\alpha$-pinene were $r_{\mathrm{S}, \max }=198.42 \mathrm{~g} \mathrm{~m}^{-3} \mathrm{~h}^{-1}$ and $K_{\mathrm{S}}=0.76 \mathrm{~g} \mathrm{~m}^{-3}$, with a regression coefficient $R^{2}=0.902$.

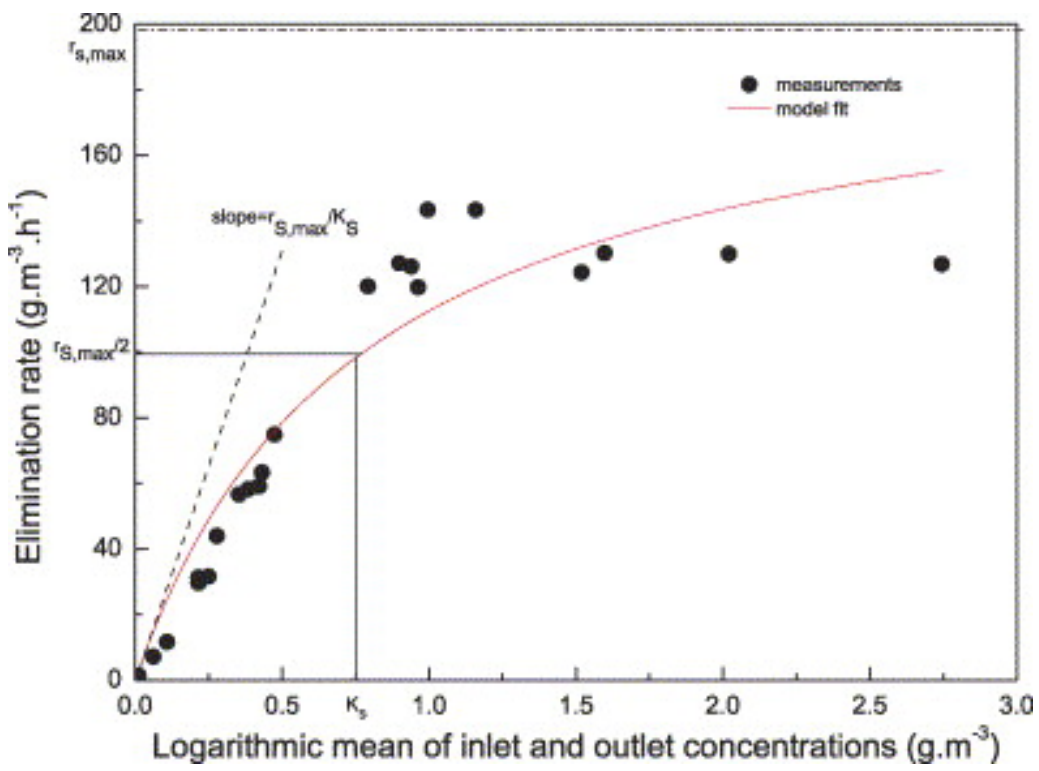

Fig. 11.

Evaluation of the elimination capacity in the biofiltration of $\alpha$-pinene at the logarithmic mean of inlet and outlet concentrations. 
In real full-scale application, these biokinetic parameters can be used for biofilter design. Unlike the rule of thumb method, these parameters come from experimental data and can better reflect the real situation. The volume of the biofilter can be calculated from the waste gas concentration $\left(C_{\mathrm{i}}\right)$, the gas flow rate $(Q)$ and the required outlet concentration after biotreatment $\left(C_{0}\right)$, by rearranging Eq. (4):

$V=\frac{Q}{r_{\mathrm{S}, \max }}\left[\left(C_{\mathrm{i}}-C_{\mathrm{o}}\right)+K_{\mathrm{S}} \ln \left(\frac{C_{\mathrm{i}}}{C_{\mathrm{o}}}\right)\right]$

\section{Conclusions}

Batch studies and laboratory scale biofilter experiments conducted with the strain Ophiostoma sp. confirmed that the fungus is able to use $\alpha$-pinene as a sole carbon and energy source and completely degrade it in both liquid and vapor phase. The fungal biofilter inoculated with Ophiostoma species was found to be more efficient than bacterial bioreactors treating $\alpha$-pinene contaminated air streams, achieving a maximum elimination capacity of $143 \mathrm{~g} \mathrm{~m}^{-3} \mathrm{~h}^{-1}$ with $89 \%$ removal efficiency, while complete pollutant degradation was reached up to a load of $100 \mathrm{~g} \mathrm{~m}^{-3} \mathrm{~h}^{-1}$. Optimal performance and maximum elimination capacity were observed when simultaneously increasing the pollutant concentration while decreasing the air flow rate, i.e. increasing the residence time. Oxygen was shown to significantly enhance the $\alpha$-pinene's removal efficiency. The kinetic parameters for the biofiltration of $\alpha$-pinene were $r_{\mathrm{S}, \max }=198.42 \mathrm{~g} \mathrm{~m}^{-3} \mathrm{~h}^{-1}$ and $K_{\mathrm{S}}=0.76 \mathrm{~g} \mathrm{~m}^{-3}$ at the optimal air flow rate of $0.055 \mathrm{~m}^{3} \mathrm{~h}^{-1}$. These kinetic parameters can be used for the design of full-scale biofilters.

\section{Acknowledgements}

The present research was financed by the Spanish Ministry of Education and Science (Project CTM2004-00427). Yaomin Jin was financially supported through a fellowship of the Agencia Española de Cooperación Internacional (AECI) and the Spanish Ministry of Foreign Affairs. 


\section{Appendix A. Nomenclature}

\begin{tabular}{|c|c|}
\hline$A$ & cross area of the biofilter $\left(\mathrm{m}^{2}\right)$ \\
\hline$B$ & biofilm density (g-cell $\mathrm{m}^{-3}$ ) \\
\hline$C_{\mathrm{i}}$ & $\alpha$-pinene inlet concentration $\left(\mathrm{g} \mathrm{m}^{-3}\right)$ \\
\hline$C_{0}$ & $\alpha$-pinene outlet concentration $\left(\mathrm{g} \mathrm{m}^{-3}\right)$ \\
\hline $\bar{C} C^{-}$ & $\begin{array}{l}\text { the mean log of the inlet and outlet } \\
\text { concentrations }\left(\mathrm{g} \mathrm{m}^{-3}\right)\end{array}$ \\
\hline$H$ & height of the packed bed (m) \\
\hline$K_{\mathrm{S}}$ & $\begin{array}{l}\text { saturation constant or half-velocity } \\
\text { constant }\left(\mathrm{g} \mathrm{m}^{-3}\right)\end{array}$ \\
\hline$Q$ & waste gas flow rate $\left(\mathrm{m}^{3} \mathrm{~h}^{-1}\right)$ \\
\hline$r_{\mathrm{S}}$ & substrate degradation rate $\left(\mathrm{g} \mathrm{m}^{-3} \mathrm{~h}^{-1}\right)$ \\
\hline$r_{\mathrm{S}, \max }$ & $\begin{array}{llll}\text { maximum } & \text { substrate degradation rate } \\
\left(\mathrm{g} \mathrm{m}^{-3} \mathrm{~h}^{-1}\right) & & \\
\end{array}$ \\
\hline $\mathrm{RCO}_{2} \mathrm{RCO} 2$ & $\begin{array}{lll}\begin{array}{l}\text { molar carbon } \\
\left(\mathrm{mmol} \mathrm{m}^{-3}\right)\end{array} & \text { dioxide } & \text { production } \\
\end{array}$ \\
\hline RC10H16RC10H16 & molar of $\alpha$-pinene removal $\left(\mathrm{mmol} \mathrm{m}^{-3}\right)$ \\
\hline$S$ & concentration of substrate $\left(\mathrm{g} \mathrm{m}^{-3}\right)$ \\
\hline$t$ & residence time $(\mathrm{h})$ \\
\hline$V$ & volume of the biofilter bed $\left(\mathrm{m}^{3}\right)$ \\
\hline$Y_{\mathrm{X} / \mathrm{S}}$ & $\begin{array}{l}\text { biomass yield coefficient based on the } \\
\text { substrate (g-cell g-substrate }{ }^{-1} \text { ) }\end{array}$ \\
\hline$Z$ & height of the biofilter (m) \\
\hline
\end{tabular}

Greek letters

\begin{tabular}{|l|l|}
\hline$\mu$ & specific microbial growth rate \\
\hline$\mu_{\mathrm{m}}$ & maximum growth rate \\
\hline
\end{tabular}

\section{References}

C. Kennes, M.C. Veiga

Bioreactors for waste gas treatment

Kluwer Academic Publishers, Dordrecht, The Netherlands (2001)

C. Kennes, F. Thalasso

Waste gas biotreatment technology

J Chem Technol Biotechnol, 72 (1998), pp. 303-319

C. Dirk-Faitakis, D.G. Allen

Development and simulation studies of an unsteady state biofilter model for the treatment of cyclic air emissions of an alpha-pinene gas stream

J Chem Technol Biotechnol, 80 (2005), pp. 737-745

J.W. van Groenestijn

Biotechniques for air pollution control: past, present and future trends

Proceedings of the international congress biotechniques for air pollution control, La

Coruña, Spain, October 5-7 (2005), pp. 3-12 
C. Kennes, M.C. Veiga

Fungal biocatalysts in the biofiltration of VOC-polluted air

J Biotechnol, 113 (2004), pp. 305-319

P.W. Trudgill

Microbial metabolism of monoterpenes-recent developments

Biodegradation, 1 (1990), pp. 93-105

N. Savithiry, D. Gage, W. Fu, P. Oriel

Degradation of pinene by Bacillus pallidus BR425

Biodegradation, 9 (1998), pp. 337-341

A. Farooq, S. Tahara, M.I. Choudhary, Atta-ur-Rahman, Z. Ahmed, K.H.C. Başer, et al. Biotransformation of $(-)$ - $\alpha$-pinene by Botrytis cinerea

Zeitschrift für Naturforschung C, 57c (2002), pp. 303-306

R. Agrawal, R. Joseph

Bioconversion of alpha pinene to verbenone by resting cells of Aspergillus niger

Appl Microbiol Biotechnol, 53 (2000), pp. 335-337

J.W. van Groenestijn, J.X. Liu

Removal of alpha-pinene from gases using biofilters containing fungi

Atm Environ, 36 (2002), pp. 5501-5508

B.D. Lee, W.A. Apel

Effect of bed medium moisture on $\alpha$-pinene removal by biofilters

Proceedings of the USC-TRG 1996 conference on biofiltration, Los Angeles, California, October 24-25 (1996), pp. 214-222

M. Mohseni, D.G. Allen, K.M. Nichols

Biofiltration of alpha-pinene and its application to the treatment of pulp and paper air emissions

TAPPI J, 81 (1998), pp. 205-211

G.T. Kleinheinz, S.T. Bagley

A filter-plate method for the recovery and cultivation of microorganisms utilizing volatile organic compounds

J Microbiol Methods, 29 (1997), pp. 139-144

G.T. Kleinheinz, S.T. Bagley, W.P. St John, J.R. Rughani, G.D. McGinnis

Characterization of alpha-pinene-degrading microorganisms and application to a benchscale biofiltration system for VOC degradation

Arch Environ Contam Toxicol, 37 (1999), pp. 151-157

M. Mohseni, D.G. Allen

Transient performance of biofilters treating mixtures of hydrophilic and hydrophobic volatile organic compounds

J Air Waste Manage Assoc, 49 (1999), pp. 1434-1441 
M. Mohseni, D.G. Allen

Biofiltration of mixtures of hydrophilic and hydrophobic volatile organic compounds

Chem Eng Sci, 55 (2000), pp. 1545-1558

E. Estévez, M.C. Veiga, C. Kennes

Biofiltration of waste gases with the fungi Exophiala oligosperma and Paecilomyces variotii

Appl Microbiol Biotechnol, 67 (2005), pp. 563-568

R.M.M. Diks, S.P.P. Ottengraf, S. Vrijland

The existence of a biological equilibrium in a trickling filter for waste gas purification

Biotechnol Bioeng, 44 (1994), pp. 1279-1287 